\title{
LANGSTON HUGHES: AMERİKALI ZENCİ BİR YAZARIN GÖZÜYLE SOVYET RUSYA VE ORTA ASYA
}

\author{
İsmail ÖĞRETIR*
}

\begin{abstract}
$\ddot{O} z$
Bu çalışmanın amacı Amerikalı zenci bir yazar olan Langston Hughes'ün 1932 yılında bir film çekimi maksadıyla Sovyet Rusya ve Orta Asya'ya yaptığı gezi sırasında edindiği izlenimleri otobiyografisi I Wonder as I Wander ışığında incelemektir. Çalışmanın birinci bölümü Hughes'ün içinde bulunduğu yirmi iki kişiden oluşan zenci bir grubun Amerika'daki zencilerin sorunlarını dile getiren bir film projesini gerçekleştirmek üzere Sovyetler Birliği'nin davetlisi olarak Moskova'ya gelişlerini, proje gerçekleşmeyince uğradıkları düş kırıklığını ve grubun dağılışını anlatmaktadır. İkinci bölümde ise Hughes ile birlikte küçük bir grubun Orta Asya'yı ziyaretleri, diğerlerinin birkaç şehri gezdikten sonra geri dönmeleri üzerine Hughes'ün tek başına geziyi sürdürmesi, birkaç ay boyunca kaldığı Aşkabat, Semerkant, Buhara ve Merv gibi şehirler ve çevredeki bazı yerleşim merkezlerinde tespit ettiği gelişmeler ve şairin değerlendirmeleri yer almaktadır. Sonuçta, alçak gönüllü bir kişi olan Hughes'ün Afrikalı Amerikalılarla Orta Asya insanını özellikle 'beyaz olmayan insan' bağlamında buluşturduğu vurgulanmaktadır.
\end{abstract}

Anahtar Kelimeler: Langston Hughes, I wonder as I wander, film projesi, Orta Asya, Afrikalı, Amerikalı.

\section{LANGSTON HUGHES: AN AFRICAN AMERICAN WRITER'S OBSERVATIONS ON SOVIET RUSSIA AND CENTRAL ASIA}

\begin{abstract}
This paper aims to examine, in the light of his autobiography $I$ Wonder as I Wander, African American writer Langston Hughes' impressions of Soviet Russia and Central Asia where he went in 1932 for a film production. The first section of the study discusses the arrival of twenty two invited African Americans, Hughes among them, at Moscow to actualize a film project which would deal with the problems of black people in America, the group's disappointment with the cancelation of the project, and the eventual separation of the group. The second section examines Hughes' and a small group's visit to Central Asia, upon the decision of the group to return to Moscow after visiting some cities, Hughes' resolution to continue the excursion alone, his discoveries and evaluations about the developments in Ashgabat, Samarkand, Bokhara, and Merv and their environs where he stayed a couple of months. Consequently it is emphasized that, as a modest person, Hughes succeeded in causing the meeting of African Americans with Central Asians particularly in a non-white context.
\end{abstract}

Keywords: Langston Hughes, I wonder as I wander, film project, Central Asia, African American.

\footnotetext{
* Doç. Dr.; Atatürk Üniversitesi Edebiyat Fakültesi, İngiliz Dili ve Edebiyatı Bölümü, iogretir@atauni.edu.tr.
} 
Amerika Birleşik Devletleri'nin Missouri eyaleti, Joplin'de 1902'de doğan Langston Hughes hayatının ilk on iki yılını Kansas, Colorado, Indiana ve New York eyaletlerinde geçirmiş, liseyi Cleveland, Ohio'da tamamlamıştır. Son sınıfta hem sınıf şairi hem de yıllık editörü seçilerek bu yöndeki yeteneklerini gösteren Hughes asıl kimliğini New York'un zenci bölgesi Harlem'de bulur. Burada çağdaşlarıyla birlikte geleneklerin dışında yeni bir hareket başlatırlar ve böylece birçok zenci yazara ve sanatçıya esin kaynağı olacak bir ortam doğar. Hughes ömrü boyunca Harlem'i evi kabul etmiştir. Şiir, roman, kısa öykü, tiyatro, çeviri, biyografi dallarında eserler veren yazar, çok sayıda ödül kazanmış, eserleri yirmi beşten fazla dile çevrilmiştir.

Langston Hughes yorulmak bilmez bir gezgin, verimli bir yazardır. Hayatı boyunca bir yandan seyahat etmiş, diğer yandan gezip gördüklerini kaleme almıştır. Şiirlerini okumak ve konferanslar vermek üzere yurt içinden ve dışından davetler alan Hughes hem kendi ülkesi Amerika Birleşik Devletlerini, hem de Batı Hint Adalarını (Karayibleri), Afrika'yı, Avrupa'yı ve Asya'yı tanıma olanağı bulmuştur. Yazar böylesine geniş bir coğrafyada elde ettiği izlenimleri iki otobiyografide toplamıştır: The Big Sea (1940) ve I Wonder as I Wander (1956). I Wonder as I Wander'da anlattığına göre Hughes, 1932 baharında Texas eyaletinde şiir okumaları yaparken, tanıdıkları aracılığıyla San Fransisco'da 'Russian Hill'de yer alan bir malikânede kalmak üzere davet alır. Ev sahibi beyaz ama mütevazı bir insandır. Birçok entelektüelin ve sanatçının ağırlandığı bu mekânda belki de hayatının en rahat, en güzel günlerini geçirir şair; bir yandan yeni insanlarla tanışır, görüşür, öte yandan California ve çevre eyaletlerdeki faaliyetlerini sürdürür. Ta ki hayatını, planlarını değiştirecek beklenmedik bir teklif alana kadar. Çok sevdiği, evi kabul ettiği Harlem'den gelen bir habere göre film çevirmek üzere zencilerden oluşan bir grup Rusya'ya gidecektir; eğer kabul ederse Hughes de bu gruba yazar olarak katılacak, İngilizce diyaloğu sağlayacaktır. Kontrat dört aylıktır ve Haziran'da başlayacaktır. Şair teklifi kabul etmekte tereddüt etmez.

Hughes Mayıs sonunda eşyalarını toplarken pek de neşeli, rahat bir yere gitmediğini fark eder. Malikâneye gelip gidenler arasında Sovyet Rusya konusunda deneyimli bir kişi vardır ve kendisine tavsiyelerde bulunur: "Yanına sabun ve tuvalet kâğıdı al ve yanından hiç ayırma" der. Bir de dudak boyası ve ipek kadın çorabı götürmesini önerir. Dolayısıyla şöyle düşünmektedir Hughes: "Bir ay içerisinde kendimi bambaşka bir dünyada buldum, Amerikan kapitalizminin doruğundan Sovyet komünizminin gösteri yerine, Russian Hill'dan Rusya'nın kendisine hızlı bir geçiş" (Hughes, 1993, s. 67). 
Bremen adlı gemiyle New York'tan Moskova'ya doğru yola çıktıklarında Hughes'ün yanında bavulları, kitapları ve daktilosu ile birlikte, bir çeşit gramofon olan victrolası ve kocaman bir kutu dolusu Louis Armstrong, Bessie Smith, Duke Ellington ve Ethel Waters plakları vardır. Blues ve caz sevdalısıdır şair; onlarsız yapamaz, nereye giderse gitsin yanında taşır. Blues zaten Afrikalı Amerikalının hüzün dolu öz yaşamından neşet etmiş kök müziğidir; Hughes şiirleriyle bunu hep yansıtmıştır. Caz ise şairin daha ötelere geçmesini, dünyaya daha fazla açılmasını sağlar. Brent Hayes Edwards, Hughes’ün daha 1924'te yazdığı “Jazz Band in Parisian Cabaret” adlı şiirini değerlendirirken 'caz' kelimesinin şairin Blues şiirlerini mevcut çerçevesinden ve Amerikan uzamından koparıp, yeni bir anlama, okyanus ötesi bir mecraya yönlendirdiğini vurgular. Cazın öyle bir yeteneği vardır ki, dokunaklı imaları değiştirir, aynı anda hem ağlatır hem güldürür (Edwards, 2003, s. 65).

Zamanla caz Hughes'ün bir parçası hâline gelir; adeta onun kimliğini sunar bize. Amiri Baraka'nın deyimiyle "Langston Caz Şairidir. Blues’un değişmez taşıyıcısıdır. Ozandır, filozoftur, halk ve kent şairidir. Onun şiiri orijinalliğiyle, duygularıyla ve toplumsal değişime açıktan teslimiyetiyle Amerikan medeniyetinin mihenk taşlarından birisidir" ("Foreword", The Big Sea, s. ii). Gerçek bir Afrikalı Amerikalı, okyanus ötesi bir sanatçı olarak misyonunu caz aracılığıyla sürdürür şair; onun ve doğal olarak Blues'un, ışığıyla yazdığı şiirler, Türkçe dâhil, birçok dile çevrilmiş ve birçok sanatçıyı etkilemiştir. Böylece şair siyahi kültürün uluslararası ortamlarda yaygınlaşmasına katkıda bulunmuştur. İşte bu açıdan Sovyet Rusya serüveni büyük anlam taşımaktadır. Yolculuğun asıl amacı, Amerika'da özellikle Güney'de yaşayan zenci halkın kapitalist sistem içinde nasıl ezildiğini ortaya koyan bir filmin çekimini gerçekleştirmektir. Her ne kadar bu proje gerçekleşmemişse de söz konusu gezi, misyonunu sürdürmede Hughes'e yardımcı olmuştur.

Zenci gençlerden oluşan 22 kişilik grup, Sovyetlerden kaynaklanan uzun süreli bürokratik işlemlerden kurtulup Berlin ve Helsinki üzerinden Moskova'ya ulaştığında Kremlin yakınlarındaki Grand Hotel'de ağırlanır. Ruslar iyi davranmaktadır; onları "Negro-workercomrades (Zenci-emekçi-yoldaşlar)" olarak benimsemişlerdir; zaman zaman onlara öncelik tanırlar. Moskova'ya ulaşıncaya kadar yaptıkları masrafların hepsi karşılanır. Tüm bunlara karşılık grup üyeleri de dikkatli olmaya çalışırlar başkentte geçirdikleri süre içinde. Aslında eğlenceli bir dönem başlamıştır onlar için; gündüzleri ilginç yerler görmeye giderler geceleri ise eğlence merkezleri ve gösteriler onları çeker. Özellikle Metropol adlı otel bu anlamda gözdeleridir çünkü bir caz orkestrasının ve dans edecek kadınların bulunduğu tek oteldir. 
Sayıları fazla olmasa da Moskova'ya önceden gelip yerleşmiş başka zenciler de vardır. Hughes bu insanların başkentin kasvetli havasına renk kattığını düşünmektedir. Doğal olarak onların varlığı grup elemanlarının yaşamlarını önemli ölçüde kolaylaştırmaktadır.

Her türlü insanla görüşmekten çekinmeyen Hughes'ün canını sıkan asıl şey Sovyet sisteminin işleyiş tarzıdır. Büyük bir heyecanla film çekmeye Moskova'ya gelen 22 cevval insanı şaşkına çeviren ilk olay bir kontratın bile imzalanmamış olmasıdır; ikincisi ve daha önemlisi ise filmin senaryosu bile ortada yoktur. Her iki sorunu da çözmek Hughes'e düşer. Fakat hem kontrat hem de senaryo Rusça yazılmıştır. Şair ikisinin de İngilizce'ye çevrilmesinde 1srarlı davranır ve bunu başarır. Ama çile bununla bitmez. Amerika'yı hiç görmemiş, çağdaş Zenci hayatını Rusça'ya çevrilmiş birkaç kitaptan öğrenmiş meşhur bir Rus yazarın ürettiği senaryo bir felakettir; Hughes okuduklarına ağlasın mı gülsün mü bilemez. Yazar, Amerika Birleşik Devletleri'nde iş ve irk ilişkilerini oldukça dramatik bir biçimde ele almıştır ama vardığı sonuçlar yaşanan gerçeklerle hiç uyuşmamaktadır. İhtimal dışında olanı, hatta imkânsızı kaleme almıştır yazar, bu yüzden insanı kahkahaya boğacak gülünçlükler ortaya çıkmıştır. Hughes'ün deyimiyle, "Yazarın yüreği doğru yerdedir ama irksal özgürlük ve 1lımlılık konusundaki kaygısı tümüyle cahilliğin köküne takılmıştır öylesine ki eseri, Don Kişot'un, bu biraz kaçık şövalyenin ne olduğunu bilmediği şeye iyi niyetle saldırdığında yiğitliğinin karşılığını bulmamasına benzemektedir.” (Hughes, 1993, s. 76).

Aslında, Comintern, yani Komünist Parti'nin dış işlerinden sorumlu üst düzey komitesinin onaylaması senaryonun kabulü için yeterlidir. Hughes senaryonun hayallere değil gerçeklere dayanan bir biçimde yeniden yazılması gerektiğini söylediğinde kendisinin yazması teklifini de reddeder; neden olarak ise kendisinin Amerika'nın Güneyinde hiç yaşamadığını, işçi olarak çalışmadığını ve sendikalardan haberi olmadığını ileri sürer. Böylece senaryodan yalnızca işçi şarkıları ve 'sprituals' kalır geriye; yetkililer bunların korunduğu bir yenisinin yazılacağını söylerler. Ama artık böyle bir senaryo yoktur; proje iptal olmuştur. Grup Odesa'ya tatile gönderilmiş ve iptal kararı onların haberi olmadan gazetede ilan edilmiştir. Doğal olarak bu olay grup üyelerinde büyük bir düş kırıklığı yaratır. Son tahlilde Washington ile Moskova arasındaki diplomatik ilişkiler uğruna Zencilerin harcandığı kanısına varırlar. David Chioni Moore, yaklaşık on beş yıllık yönetimden sonra Sovyetler Birliği’nin Amerika Birleşik Devletleri'nden daha yakından tanınmayı beklediğini, dolayısıyla Rusların Amerikan yetkililerini gücendirecek filmlere temkinli yaklaştıklarını ileri sürmektedir (Moore, 2002, s. 
1116). Yine de içlerinden bir grup Comintern ile görüşmeye gider ve sert bir dille şikâyetçi olur ama yapacak bir şey yoktur, artık veda zamanıdır.

Bütün olumsuzluklara rağmen bu entelektüel grubun Sovyet Rusya gezisinden kazanımları vardır. Yeni yerler görmenin, yeni insanlar tanımanın yanında hepsi insanca muamele görmüşler, renklerinden dolayı aşağılanmamışlar, lüks otellerde misafir edilmişlerdir. Oysa Amerika'da o yıllarda lüks otellerde zencilerin kalması yasaktır. Toplum yaşamının hemen her noktasında Zencilere ayrılmış yerler vardır; otobüsler buna başka bir güzel örnektir. Rosa Parks isyanına kadar Zenciler hep kendilerine ayrılan arka kısımda oturmak zorundadırlar. 1955 'te Rosa otobüste beyazlara ait yere oturunca ortalık karışır; mahkemeler, boykotlar derken bu kural değişir. Oysa Hughes Sovyet Rusya'da bu sorunun daha önce çözüldügünü fark etmiştir; Çarlık Rusya'sında Asyalılar için de arkada bölmeler vardır ama Sovyetler bunu kaldırmıştır. Kısacası, film grubu kısa süreliğine de olsa Jim Crow trajedisinden, ırk ayrımcılığından uzak kalmıştır. Ayrıca Moskova'nın sadece özgürlüğünden değil, entelektüel ve kültürel ortamından da yararlanırlar. Örneğin, Hughes, Bolshoi Opera House’ta Alexander Pushkin'in “Eugene Onegin” adlı şiirinin bir performansına katılırken ünlü film direktörü Sergei Eisenstein tüm gruba bir parti verir. Hiç kuşkusuz fırsatları en iyi değerlendiren Hughes olmuş, başkentin ötesindeki yerlere gitmeyi planlamış ve gerekli izni kopardıktan sonra Orta Asya'ya doğru yelken açmıştır.

\section{Orta Asya}

Kontrat feshedilip grup dağılma eğilimine girdiğinde kimileri doğrudan Amerika'ya dönmüş, kimileri Paris veya Berlin gibi Avrupa kentlerinde oyalanmayı yeğlemiş, üç kişi sürekli Sovyetler' de kalmak için başvuruda bulunmuş diğerleri ise Soviet Trade Union'dan gelen bir teklifi kabul ederek ülkenin başka bir bölgesine doğru yola çıkmıştır. Tabii ki bunlar arasında Hughes başı çekmektedir. Ömrü boyunca seyahat eden, durmadan yer değiştiren, bir yerde altı aydan fazla kalmanın karışıklık doğuracağına inanan şair için bu bulunmaz bir firsattır. Küçük grup çok kısa sürede gideceği yeri belirler: hedef Sovyet Orta Asya’sıdır, yani Türkmenistan. Nedeni de ilginçtir: beyaz olmayan vatandaşların çoğunlukla yaşadığı bölge burasıdır. Hughes'ün sürekli vurguladığı gibi Türkmenler, Kırgızlar, Kazaklar, Özbekler ve diğerleri hep kendileri gibi beyazlar tarafından ırk ayrımına tabi tutulmuş insanlardır. Onlarla tanışmak, görüşmek bu zenci grup için büyük bir şanstır. Fakat önlerine bürokratik bir engel çıkar; o dönemde Türkmenistan'ı ziyaret yasaklanmıştır. Ancak özel izinle girilebilmektedir bölgeye. Yine iş Hughes'e düşmüştür. Şair yalnız gezmek değil aynı zamanda Orta Asya 
hakkında Amerika'da yayın yapmak üzere basın izni ister. Sinema işlerinde görevli Kremlin'e yakın birisi olan Constantine Oumansky sayesinde kendisine ve gruba izni koparır. Grup içindeki bir kıza bu görevlinin duyduğu ilgi de iznin çıkmasında etkili olmuştur.

On günlük bir turdur hedeflenen. Sonunda grup Hughes'ü Orta Asya'da birakıp Tiflis, Rostov ve Karkov üzerinden Moskova'ya dönecektir. İlk hedef ise bölgenin başkenti Taşkent'tir ve beş günlük zor bir tren yolculuğu beklemektedir onları. Avrupa tarafındaki lüks ekspres trenler henüz bu bölgeye ulaşmamıştır. Ama ne şair için ne de grup için önemlidir bu çünkü onlar Jim Crow trenlerinde kendilerine ayrılmış vagonda seyahat etmeye ve restorana sokulmamaya alışmışlardır. Önemli olan varacakları yere ulaşmaktır onlar için. Gerçekten de Taşkent'e ulaştıklarında büyük bir törenle karşılanırlar. Genç bir Amerikalı zenci ile birlikte ulusal giysileri ve peçeleri içinde Özbekler, Türkmenler ve Tatarlar kendilerini meyveler ve çiçeklerle karşılar. "Gecenin havasında Orient'in kokusu vard1- her yerde Doğu'nun bir parçası gibi görünen misk, karpuz ve toz karışımı bir şey. Bu koku, sokak ışıklarını çoğaltan hafif karanlıktaki cılız alevler ve şurada burada kısık sesli bir ut (kopuz) namesi, bir partiye doğru yol alırken ilk izlenimlerimdi” (Hughes, 1993, s. 105).

Hughes bu güzel izlenimlerin yanında gezinin sıkıntılı, yorucu yönlerini de dile getirir. Bir kere Moskova ve Odesa'da yaşadıkları rahatı burada bulamazlar. Kendilerine eşlik eden Rus görevliler onlara bir yandan turistik yerleri gezdirirken diğer yandan bazı delegasyonların hazırladığı konuşmalara katılmak zorunda kalırlar. Konuşmalar bilmedikleri bölgesel dillerde yapılmakta ve İngilizce'ye çevrilmektedir; bu da son derece yorucudur. Günün sonunda bitkin düşerler. "Yeter artık, toz ve güneş, istatistikler ve nutuklar" şeklinde şikâyetler yükselmektedir. Grubun diğer üyeleri Semerkant ve Buhara'ya ancak dayanabilirler. Son durak olan Aşkabat onlar için artık züldür; orada kalmak istemezler. Hughes'ü de vazgeçirmeğe çalışırlar. Oysa şair için keşfedilecek çok şey vardır daha. Kendisini Aşkabat istasyonunda trenden indirdiklerinde onlarla vedalaşmak bile istemez. Hatta lanet bile okur arkalarından "Hepinizin canı cehenneme! Umarım hiç birinizi bir daha görmem," der içinden. Tek başınadır artık eşyaları ve plaklarıyla.

Hughes için buraya kadar Orta Asya serüveninin birinci safhasıdır. Bundan sonra daha rahat gözlemleyip yazacaktır; bu ateş hiç sönmemiştir içinde. Daha grupla birlikte Semerkant ve Buhara'da iken bize izlenimlerini aktarmaya başlamıştır. Örneğin efsanevi Semerkant'ta Bibi Hanım Camisi ve bazı diğer hoş yerlerden çok yapılmakta olan Üniversite'yi gezdiklerinden söz eder. Bölgedeki memurların görmek istediği şekilde bazı değişikliklerin olduğunu fark eder ama değişmeyen şeyler de vardır; örneğin binlerce kadın çarşaflı ve peçelidir, müezzinler yüksek 
kulelerden insanları namaza çağırmaktadır. Pazar yerleri hala pistir. Bir editör aracıllı̆ıyla bir misafirhaneye yerleştiğinde Aşkabat'ta da benzer durumlarla karşılaşır. Ama bu kentin bir avantajı vardır; hem kent hem de kaldığı yer son derece sakindir. Yani yazma eylemi için çok elverişlidir. Kendisini yalnız hissettiğinde ise plakları yanı başındadır; caz imdadına yetişiverir. Bir süre sonra zaten odası sosyal bir merkez hâine gelecektir, kendi tahminine göre müzik sayesinde.

Odasının müdavimleri arasında önemli bir şahsiyet vardır: Arthur Koestler. Bir gün yazma eylemine daldığı sırada kapısını çalıveren bu kişi Macar Yahudi'si, Komünist Parti üyesi bir yazardır. Almanca, Fransızca, İngilizce ve Macarca bilir ve her ortamda not tutmasını becerebilen bir inandır. Bir tek kişinin bile İngilizce bilmediği bir ortamda Koestler, Hughes için çöle inen bir melek gibidir. Entelektüeldir, Parti üyesi olduğu için hem Ruslarla hem de bölgedeki görevlilerle yakın temas halindedir; Türkmenistan'da Komünistlerin icraatlarıyla ilgili her şeyin bilincindedir. Dolayısıyla sıkıntı çekmez, doğal olarak Hughes'e de yardımcı olur. Fakat iki yazar arasında ayrılıklar da söz konusudur. Öncelikle insana bakış açıları farklıdır. Zaten biri zenci, diğeri beyazdır. Bulundukları yer açısından değerlendirildiğinde Hughes tüm Orta Asya'da yaşayanlarla özdeşleşmişken Koestler'in ne Ruslardan ne de Türkmenlerden hoşlandığı söylenebilir. Koestler'in en büyük gerekçesi sağlık koşullarıdır. Bu konunun üzerinde çok fazla durur; ona göre Ruslarla Asyalılar oldukça kalın bir kir tabakası oluşturmuştur. $\mathrm{Bu}$ yüzden otele her dönüşünde yıkanmaya çalışır. Hatta şöyle söylemekten kendini alamaz: "Eğer bu devrim Almanya'da gerçekleşmiş olsaydı en azından temiz bir devrim olurdu" (Hughes, 1993, s. 115).

Dönemin koşullarını düşündüğümüzde Koestler'in abarttığı kanısına varabiliriz. Fakat bu biraz da alışkanlık meselesidir; insan bazı şeylere sonradan alışabilir ya da alışamaz. İki yazar arasındaki fark çay içme törenlerinde daha açık bir biçimde karşımıza çıkar. O dönemde Orta Asya'da çay çayhanelerde olsun evlerde olsun tasla içilmekte, çayı içen tası yanındakine uzatmakta, son kişi içene kadar bu böyle sürüp gitmektedir. Bunu gören Koestler tiksindiğini belirtir hatta tas dolaşım ritüeli başladığında bildiği dillerde küfür bile eder. Oysa Hughes, başlangıçta biraz zorlansa bile, kısa sürede olayı yadırgamaz hale gelir; onun için tas değişimi dostluk ritüelinin bir parçasıdır. O, olaylara ve insanlara ve Sovyet Asya'sındaki değişimlere, Amerika'da birçok haktan yoksun zencilerin gözüyle bakmaktadır. Burada da Türkmenler birtakım haklara henüz kavuşmamışlardır. Bu benzerliği Koestler'e bir türlü anlatamayan şair bunu şöyle özetlemektedir: “ Koestler’e göre Türkmenistan yirminci yüzyıl medeniyetine doğru 
devinen ilkel bir ülkeydi. Bana göre ise şimdiye kadar beyazlara tahsis edilen yörüngelere doğru devinen beyaz olmayan bir ülkeydi” (Hughes, 1993, s. 116). Moore, Hughes’ün bu üstünlüğünü şairde keşfettiği, genel söylemin aksine köksüz değil köklü bir kozmopolitan ikiliğe bağlamaktadır. Eleştirmene göre bunun temelinde şairin engin ruh cömertliği, ender kişiliğindeki karışıklık ve yerel/küresel 'renk' konusundaki ince anlayışı yatmaktadır. Moore yine Orta Asya gezisinden bir örnek verir: Hughes Taşkent'te Orta Asyalı göçerlerle dolu bir otel odasında kendisini tuhaf bir şekilde evinde hisseder ama aynı zamanda ortalığ canlandırmak, neşelendirmek için yanından hiç ayırmadığı victrolasına bir Louis Armstrong plağ koyuverir (Moore, 1996, s. 54).

İnsanlara ve olaylara bu kadar olumlu bakan birisi olduğu halde Hughes'ü isyan ettirecek ortamlar bulunmaktadır Orta Asya'da. Aşkabat'tan Merv'e bir gezi planlanmıştır. Hughes ve Koestler ile Charlie Kikilov ve Kolya Shagurin adlı yazarlardan oluşan ekip, Kolya'nın deyimiyle medeniyetin beşiği, dünyanın başladığı yer ve Cennet Bahçesi olan Merv vahasına varır. Merv gerçekten çölde bir vaha gibidir ama pislik peşlerini orada da bırakmaz; kaldıkları otel berbattır. Üstelik üç kişi bir yatakta yatmak zorunda kalırlar. Hughes ırk ayrımı olmadan orada kaldığına sevinirken otelin kirine dayanamaz ve kendi elleriyle temizlik yapar odada ve bunu arkadaşlık adına yaptığını söyler. Aynı grup Aitakov adlı bir Kolhoz'a da gider; eski bir otomobilde altı kişidirler ve Kolhoz'a varıncaya kadar canları çıkar. Öylesine ki Hughes bir daha hiçbir yere seyahat etmeyeceğine yemin eder. Gerçi Kolhoz'da iyi karşılanırlar, gerçekten yemyeşil güzel bir yerdir burası. Tek sıkıntı Türkmen kadınlarının kendilerine yüz vermemiş olmasıdır.

Diğer ikisi ortadan kaybolduğu için Hughes ile Koestler'in yaşadığı daha dramatik bir olay vardır. Kara Kum'dan geçip görevli gittikleri Permetyab adlı 'collective'de adeta cehennem azabı çekerler. Yolculuğun başında yanlarındaki Rus Parti görevlisi kendilerini uyarır; burada Beluciler yaşamaktadır ve Afganistan ve Hindistan'dan göç etmiş bu insanlar çekinmeden insan öldürecek kadar yabanidir. Yol berbattır, iki sefer tekerlek patlar, kuma saplanırlar ama sonunda koyun derisinden yurtlardan oluşan köye varırlar. Doğal olarak imkansızlıklar içindeki köyde hayat perişandır; susuzluk nedeniyle hijyenik bir ortam sağlanamamakta, hastalıklar kol gezmektedir. Ama hemşire-doktorun verdiği bilgiye göre en korkuncu nüfusun yüzde doksanında sifilis bulunmasıdır. Zorlanarak öğle yemeğini yerler ve yine tas yöntemiyle çaylarını içerler. Aynı gün işleri bitip gece yarısı Merv’e geri döndüklerinde Koestler Rus yetkililere niye onlara nereye gittiklerini söylemediler diye serzenişte bulunurken 
Hughes daha yoldayken kendi kendine şöyle söylenmektedir: "Eğer bir kere Merv'e, oradan Moskova'ya, sonra da Harlem'e, eve ulaşırsam sonsuza dek orada kalacağım" (Hughes, 1993, s. 127).

Hughes'ün insan sevgisi ve sanatçı kişiliği kendisine böylesi ortamları unutturacak kadar baskın çıkar zaman zaman. Bir başkası bu noktada Rusya'yı terk edebilirdi ama o kalma konusunda 1srarlıdır. Müzik ve dans en büyük yardımcısıdır. Merv'deki bir partide yemekten önce Türkmen bir grup şarkılar söylemeye başlar ve şair bu müziğe bayılır; dünyanın en haraketli, en yabani müziği Flamenko ile karşılaştırır; ona göre Türkmen Flamenko'su daha baskındır. Bütün gece bu müziği dinlemek ister şair ama yemek saati gelmiştir, müzik kesilir. Tabii yemekte önce çorba içilir ama on beş yirmi kişiye iki kaşık düşmektedir; çorba da çay gibi sırayla tüketilmektedir. Hughes bunu, paylaşmaya dayanan Tükmen konuk severliğine verir. Devamında ise koyun yahnisini elleriyle yiyeceklerdir.

Hughes için Buhara yüce, kutsal bir mekândır; tarihi bir kent olan Buhara'da camiler vardır, yüzlerce müezzin ezan okumaktadır, Asya'nın en Müslüman şehirlerinden birisidir. Fakat Hughes başka bir pencereden de bakmaktadır Buhara'ya. Tarihçilerin söylediklerine göre devrim öncesinde şehir bozulmuştur, bu anlamda Chicago'ya benzemektedir. Dinî işlere bakan Reis ile bölgeyi yöneten Emir despotça davranır olmuşlar, halkı ezmişlerdir. Yeni yönetim duruma el koymuş sorunları çözmeye çalışmaktadır. Hughes, Emir’in zulmettiği bir kişiyi örnek alır ve onun çektiklerini anlatır bize. Hacı Mir Baba Murcin adlı bu kişi sonunda Moskova’ya gidip Lenin'e yaralarını göstermiş ve Komünist olmuştur.

Oysa Yahudiler için durum biraz daha farklıdır Buhara'da. Koestler sayesinde Hughes bir Yahudi bölgesi keşfetmiştir. Yaklaşık on bin Yahudi yaşamaktadır burada; Sinagoglar da vardır; Emir onların bölgesini ayırmıştır. Ama Sovyet rejimi dinleri göz ardı ettiği için herkesi eşit koşullara taşımaya çalışmış, azınlıklar arasındaki ayrılıkları ortadan kaldırmıştır. İslam dini gibi Yahudilik de etkisini yitirmiş, bazıları Partiye katılmış, bazı Sinagoglar ticarethaneye dönüştürülmüş, Davut Yıldızı'nın yerini orak çekiç almıştır.

Koestler ile Taşkent'te son buluşmaları Sovyet rejimine bakış açılarının yavaş yavaş değiştiğini, iyimserliklerinin eridiğini göstermektedir. Daha önce Buhara'da otelde yaşadıkları bir olay bir bakıma bunun tetikleyicisi gibidir. Otele gelip temizlikçiden eşyalarını yerleştirmesini istediklerinde kadın yapmayacağını söyler. Sovyetlerde herkes sadece kendi işini yapar, fazlasını yapmazmış. Bu, bir türlü akıllarına yatmaz. Daha sonra Taşkent’te bunu ve 
başka olayları değerlendirdiklerinde en azından o bölgede devrimin başarılı olmayacağ kanısına varırlar. Özellikle Koestler'e göre Taşkent kirlidir, çirkindir, toz toprak içindedir; hapishaneler insanlarla doludur. Halk açtır, kıtlık içindedir; üzümle ve karpuzla yaşamını sürdürmek zorundadır. Hughes'e göre burası Koestler için bir dönüm noktasıdır; yazar soldan sağa kaymaktadır.

Bu noktada Koestler Moskova’ya doğru yola çıkar. Hughes yalnız kalmıştır bir bakıma. Üstelik bir süre sonra bakıma muhtaç hale gelecek kadar hastalanır. O ana kadar yaşadıklarının kendisini zayıf düşürdüğünü düşünmektedir. Yaşlı bir kadın kendisiyle ilgilenir; ayrıca yalnız kalmasın diye onu Yusuf Nişan adında Özbek bir delikanlının odasına taşırlar. İki doktor muayene eder kendisini: birinci doktor yanlış bir ilaç verir, bu yüzden daha kötüleşir, ikincisi ise bir diyet uygular ve zamanla iyileşir. Bu hastalık sayesinde dostlar edinmiştir: yaşlı kadın ve Nişan. Özellikle Nişan, gezinin geri kalan bölümünde kendisine yarenlik edecektir. O güne kadar tanıdığı insanlar arasında en arkadaş canlısı, en düşünceli, en anlayışlı ev sahiplerinden birisidir. Kültür Fizik Direktörü görevini yürüten bu delikanlı görmüş geçirmiş öksüz bir kişidir; kendisini bir bakıma devrime adamıştır. Hatta bir heykeltıraş, örnek bir Sovyet genci olarak kedisinin heykelini yontar. Abisi ile birlikte Hughes'ün hayatına girmişler farklı kişilikleriyle yerel yaşamdan örnekler sunmuşlardır. Nişan, abisi adına şairden borç para alır fakat abisi borcunu ödemez; bu da sorun yaratır. Üstelik sonradan anlaşılır ki abisi söz konusu parayla karısını satın almıştır. Her halde bu başlık parasıdır. Hughes bunu bir türlü anlayamaz. Zaten Nişan da böyle bir uygulamaya karşıdır: "Ne Sovietiski!" der. Sovyet kurallarına aykırıdır bu gelenek ama yapacak bir şey yoktur; Nişan yıllar sonra abisine kavuşmuştur, ne onu kaybetmek ister ne de Hughes'ü üzmek; yapabileceği tek şey oturup ağlamaktır. Hughes yine de abinin düğün törenine katılır ve şu sonuca varır: bunlar kardeştirler ama biri devesiyle Mekke’ye, diğeri ise otomobiliyle Moskova'ya yönelmiştir.

Nişan gibi birçok insanla tanış olmuş, dostluklar kurmuştur Hughes. Arkadaşı Arnold Rampersad'in tespitine göre bunu şöyle başarmıştır: "Her yerde Hughes için en önemli şey öyküsünün kişisel, insani unsurudur- kendi öz tepkileri, bireylerle karşı karşıya gelmesi, sıradan insanların yaşamlarına içten gelen neredeyse önlenemez bir hissin etkisiyle girme arzusu; böylece yad ellerde hiç yabancılık çekmez. Başkaları 'ilkel' halklar arasındaki sağlıksız koşullardan kendilerini geri çekerken, ya da genellikle sınıfa ve ırka dayalı kısıtlamalar ve ayrıcalıklarda 1srar ederken Hughes alışkanlıklarında ve ritüellerinde yığınlara katılır ve bunu 
ideolojiye başvurmadan, hayatına damga vurmuş insan sevgisiyle yapar" (Hughes, 1993, s. XVII).

Genellikle bireyi öne çıkaran Hughes toplumcu bakış açısının cazibesine de kapılmıştır zaman zaman. Örneğin, bölgenin önde gelen tiyatro yazarı İsmailov ile yaptı̆̆ görüşmeler sonucunda Taşkent'te açılacak Özbek ulusal tiyatrosunun amacını benimser görünmektedir. Aynen şöyle söyler İsmailov: "Biz tiyatroyu halka, eğer geçmişin eskimiş çirkin bencil adetlerini yok edersek yaşamın ne kadar güzel olabileceğini öğretmek için kullanmaya çalışıyoruz. Ve farklı uluslarımıza Türkmen Özbek'le, Tacik Tatarla ve Rus Asyalıyla nasıl anlaşacak bunu göstermeye çalışıyoruz. Ben oyunlarımda hepimizin yoldaş olması gerektiğini söylemeye çalışıyorum" (Hughes, 1993, s. 173). Hughes buradaki görüşü pek istemese bile desteklemektedir. Sanatın propagandaya dönüşmesini yozlaşma olarak değerlendirir ama yetenekli ellerde propagandanın dramatik boyutlar kazandırabileceğine de inanmaktadır. Oysa daha önce Koestlerle bir konuşmasında yazar Komünist Partiye niye katılmadığını sorunca Partinin disiplin ve direktiflere önem verdiğini, bunun da yaratıcı yazarlığa zarar vereceğini söyler. Koestler ise bazı tarihi dönemlerde kolektif toplumsal amaçların bireysel arzuların ötesine geçebileceği düşüncesindedir. Bir başka ortamda Hughes Partiye üye olmamasını Rusların caz müziğini resmi platformda tabu olarak görmesine bağlar; onlara göre caz çürümüş burjuva müziğidir. Hughes'ün buna cevabı ise çok nettir: "O benim müziğim ve bir dünya devrimi için ondan vaz geçmem”( Hughes, 1993, s. 122).

Bu iddialı sözler bir bakıma Hughes'ün yaşam felsefesine işaret etmektedir. Şair her şeyden önce özgürlükten yanadır, ondan hiç taviz vermek istemez. Adeta özgürlük ile evlidir. İnsan sevgisiyle dolu olarak sanatçı kişiliği ve yeteneği sayesinde her türden insanla özellikle halkla kolayca ilişki kurabilmiş ve birçok şeyin farkına varmıştır. Örneğin şu tespiti son derce evrensel boyuttadır: “....sadece Sovyetler Birliği'nde değil bütün dünyada - hemen hiçbir şeyi olmayan yerlerde bile, zenginler, güzeller, yetenekliler veya çok zekiler daima bir şeyler elde eder; aslına bakarsanız, var olanın en iyisini” (Hughes, 1993, s. 182).

Hughes için Orta Asya'yı terk etme noktası olan Semerkant ile ilgili şu izlenimleri Sovyetler Birliği’nin kurulmasıyla birlikte neyin değiştiğine ilişkin bir fikir vermesi açısından önemli görünmektedir:

“SEMERKANT! Yeşil- kıvrımlı Semerkant! Timurlenk'in şehri, Dünya Sarsıcısı; ondan önce Cengiz Han'ın şehri, Moğolların lideri; ondan önce Büyük İskender'in spor sahası, 
kapılarının dâhilinde eski arkadaşını öldürdügüu, Clitus'u, üç bin yıl önce ikisi de şarapla sarhoş iken. Semerkant, on ikinci yüzyllda Arap kültürünün serpilen merkezi; Uluğ Bey’in kadim rasathanesinin olduğu yer; Orta Çağda Çin'den ipek, Semerkant'tan baharat bekleyen Venedikli tacirler için altın bir ad; Doğulu şairler için tatı bir şarkı-şehir; turkuaz kubbelerin şehri Semerkant! Yeşil - kıvrımlı Semerkant.

Günümüzde eski Semerkant dökülen ihtişamıyla isteyen herkesin görüşüne açıktır. Yeni Semerkant bir ipek fabrikası ve bir Komünist Üniversitesidir, bir hidro-elektrik santrali ve T1p Fakültesidir. Sovyet Rehber Kitabına göre o, kurutulmuş meyve, üzüm, pirinç, işlenmemiş deri ve şarap erzakının ticari dağıtım noktasıdır. Ana caddesinin adı şimdi Karl Marks Caddesi'dir” (Hughes, 1993, s. 184).

Moore 1998 yılında Orta Asya'ya yaptığı bir geziye ait izlenimlerini aktarırken Hughes'ün izini sürdüğünü, şair ile temas etmiş kişilerin yakınlarıyla görüştüğünü, Stalin'in yok edici uygulamalarına rağmen bazı bilgilere ulaşabildiğini belirtmektedir. Bir yandan şiirlerinin Özbekçeye çevrildiği haberini verirken diğer yandan Hughes'ün Taşkent'e, Semerkant'a, Buhara'ya duyduğu hayranlığı kendisinin de yaşama imkânı bulduğunu dile getirmektedir. (Moore, 2002, s. 1128-35) Moore'un bu çabası hem Hughes'ün gerçekleşmeyen bir film projesi sayesinde Afrikalı Amerikalılarla Orta Asya insanını daha 1932'de, 'beyaz olmayan insanlar' bağlamında tanıştırarak önemli bir hizmet gördüğünü hem de Orta Asya'nın bütün değişikliklere rağmen, Sovyetler Birliği'nin dağılmasından sonra da benliğini koruduğunu göstermektedir.

\section{Kaynaklar}

Baraka, A. (1989). "Foreword", in Langston Hughes. The Big Sea: An Autobiography, New York: Thunder's Mouth Press.

Edwards, B. H. (2003). The practice of diaspora: literature, translation, and the rise of black internationalism. Cambridge, Mass: Harvard University Press.

Hughes, L. (1989). The big sea: an autobiography. New York: Thunder's Mouth Press.

Hughes, L. (1993). I Wonder as I wander: an autobiographical journey. New York: Hill and Wang.

Moore, D. C. (1996). Local color, global 'color': Langston Hughes, the Black Atlantic, and Soviet Central Asia, 1932. Research In African Literatures (Bloomington, IN) (27:4) (Winter), s. 49-70.

Moore, D. C. (2002). Colored Dispatches from the Uzbek Border: Langston Hughes's Relevance, 1933-2002. Callaloo 25.4, s. 1115-1135.

Rampersad, A. (1986) The life of langston hughes, volume i: 1902-1941: i, too, sing America. New York: Oxford University Press.

Rampersad, A. (1993). "Introduction", in Langston Hughes, I Wonder As I Wander: An Autobiographical Journey. New York: Hill and Wang. 